\title{
Kobieta na dachu świata, czyli kilka słów o historii oraz wizerunku medialnym Wandy Rutkiewicz
}

By dobrze zrozumieć drogę, jaką musiała pokonać Wanda Rutkiewicz z miejskich nizin na najwyższe góry świata, należy przynajmniej fragmentarycznie poznać historię, lub raczej specyfikę, himalaizmu, a w szczególności historię kobiecego wspinania. Przez przeważającą część czasów nowożytnych wyrażenie „kobieta-wspinacz” stanowiło bowiem oksymoron. Kobiety bywały prawie wyłącznie żonami, matkami, powierzane im były role przypisywane do sfery prywatnej, a ich udział w życiu publicznym był znikomy. Tylko arystokratki czy damy z tzw. dobrych domów mogły sobie pozwolić na nieco więcej ekstrawagancji w codziennym życiu, a właśnie tak traktowane było eksplorowanie kolejnych zakątków Ziemi. To przecież mężczyźni byli pierwszymi odkrywcami mórz, pustyń, biegunów oraz gór. Umożliwiało im to, inaczej niż kobietom, zarówno ich otoczenie kulturowe, jak i posiadane majątki. Nawet jeśli nieliczne $z$ kobiet, które miały finansową i społeczną niezależność pozwalającą wyjść poza wąskie schematy tamtych czasów, chciały wyruszyć w świat gór, nie były zapraszane do uczestnictwa w wyprawach, gdyż te traktowane były wyłącznie jako „męskie rozrywki”. Zresztą „kobiece wejścia” stanowią po dziś dzień jedynie około 5,4\% wszystkich wejść na najwyższe góry świata ${ }^{1}$.

Początki kobiecego himalaizmu przypadają na koniec XVIII wieku, kiedy to pierwsza kobieta obwiązała się liną wokół talii ${ }^{2}$, aby piąć się po stromych zboczach.

\footnotetext{
${ }^{1}$ J. Jordan, Okrutny szczyt, Wrocław 2007, s. 18.

2 Zob. szerzej: P.H. Hansen, The Summits of Modern Man: Mountaineering after the Enlightenment, Cambridge-Massachusetts-London 2013.
} 
Od tego czasu kobiety musiały zmagać się nie tylko z górami, lecz także, a może przede wszystkim, z własną płcią i społecznymi rolami, które im przypisywano. Kobiece doświadczenia ze wspinaczką znacznie różniły się od tych, które były udziałem mężczyzn. Pierwsze alpinistki spotykały się z oporem i irytacją światłych kręgów społecznych, którym z trudem przychodziło zaakceptowanie widoku kobiety ubranej w spodnie lub spódnicę skróconą do łydek, obwiązaną ciasno liną i wspinającą się na górę ${ }^{3}$ I o ile ryzykowanie życiem przez mężczyzn nie budziło społecznego sprzeciwu, kobiety (które przez wspinanie zapuszczały się na zwyczajowo męskie terytorium) wywoływały niezrozumienie, irytację i sprzeciw. Mężczyźni często czuli się skonfundowani, wręcz pokonani, gdy kobiety osiągały te same wyniki, którymi oni się wcześniej szczycili, twierdząc, że przekraczają granice wytrzymałości ludzkiego organizmu. W końcu skoro kobieta mogła to osiągnąć, to co było w tym niebezpiecznego? Kobieta wspinająca się na odległe górskie szczyty nie pasowała do panujących wówczas norm kulturowych, które przypisywały jej zupełnie inne role.

Mimo powszechnego braku akceptacji także kobiety zapisały się na kartach historii alpinizmu czy himalaizmu. W 1838 roku miało miejsce pierwsze, samodzielne kobiece wejście na Mont Blanc, w 1871 roku na Matterhorn, a w 1975 roku na Mount Everest ${ }^{4}$. Pierwsze $\mathrm{w}$ pełni kobiece wejście ( $\mathrm{w}$ zespole kobiecym, co wymaga podkreślenia) miało miejsce w 1974 roku, gdy trzyosobowy zespół Japonek dotarł do wierzchołka Manaslu (8156 m), ósmego co do wysokości szczytu świata. Rok później Polki - Anna Okopińska i Halina Krueger-Syrokomska zdobyły wysoki na 8035 m Gaszerbrum II „bez tlenu”, zaś w 1975 roku Japonka Junko Tabei została pierwszą kobietą, która stanęła na dachu świata, czyli na Mount Everest (8848 m). Jednak do 1964 roku, kiedy zostały zdobyte już wszystkie czternaście ośmiotysięczników, żadna z wspinających się kobiet tego nie dokonała.

Ten męski, niebezpieczny świat pociągał także Wandę Rutkiewicz. Charakter Wandy został w znacznej mierze ukształtowany już we wczesnych latach dzieciństwa. Gdy w 1939 roku Niemcy dokonały inwazji na Polskę, Zbigniew Błaszkiewicz (ojciec Wandy) - inżynier zbrojeniowy w Radomiu - postanowił wyemigrować na Litwę, gdzie poznał i poślubił Marię Tyszkiewicz (matkę), którą można by dziś określić mianem zanurzonej w ruchu New Age ze względu na zamiłowanie do okultyzmu i dalekowschodnich religii ${ }^{5}$. W 1943 r. urodziła się Wanda, a niedługo potem cała rodzina Błaszkiewiczów przeniosła się do Wrocławia. To tam, w 1948 roku, „bycie dziewczyną" w bardzo dotkliwy sposób po raz pierwszy odcisnęło piętno na jej życiu. Pewnego razu brat Wandy wraz z kolegami znaleźli wśród gruzów niewypał, kazali jej pójść do domu, gdyż w ich odczuciu nie była to zabawa dla dziewczynek. Gdy

\footnotetext{
${ }^{3}$ Ibidem.

${ }^{4}$ Ibidem.

${ }^{5}$ Pisze o tym m.in. A. Kamińska, Wanda. Opowieść o sile życia i śmierci. Historia Wandy Rutkiewicz, Kraków 2107, s. 34.
} 
zapłakana Wanda poszła poskarżyć się matce, doszło do eksplozji, w której wszyscy chłopcy zginęli. Wiele lat później Wanda miała powiedzieć: „Nie byłoby mnie tu, gdyby siedmioletni chłopcy potrafili bawić się z pięcioletnimi dziewczynkami”"6. Jako najstarsza z rodzeństwa dość szybko musiała przejąć znaczną część obowiązków $\mathrm{w}$ domu, a ojciec traktował ją po trosze jak syna. To on zaraził ją miłością do sportu, choć - jak wielokrotnie podkreślała $\mathrm{w}$ wywiadach - tym, co najbardziej pociągało ją w sporcie, była rywalizacja. Lubiła być pierwszą, zarówno konkurując w skoku wzwyż, rzucie oszczepem, dyskiem czy pchnięciu kulą, jak i wtedy, gdy, grając w siatkówkę, zakwalifikowała się do kadry olimpijskiej. W wieku 22 lat ukończyła studia na Politechnice Wrocławskiej, a jej zawodowa kariera związana była z pracą przy rdzeniach magnetycznych. Także wspinać się zaczęła z przytupem, choć jak sama przyznawała $\mathrm{w}$ jednym $\mathrm{z}$ wywiadów: „Od razu weszłam $\mathrm{w}$ jakiś określony tradycją układ typu: "baby to się nie nadają, są słabsze«"”.

Temat płci i podziału ról był stałym motywem życia górskiego Wandy. Środowisko męskie dość szybko przypięło jej łatkę feministki, nad czym zresztą, jak można wywnioskować z jej wypowiedzi medialnych, wcale nie ubolewała. Wychodziła bowiem poza wiele utartych schematów. Stereotyp delikatnej, niesamodzielnej żony, która siedzi w domu u boku męża, zupełnie do niej nie pasował. Ważna była dla niej rywalizacja, która - jak pisze we wstępie do książki Wszystko o Wandzie Rutkiewicz. Wywiad rzeka Barbary Rusowicz Krzysztof Zanussi — ,jest jednym z dwóch elementów, dla których ludzie się wspinają" i kontynuuje:

Jeśli z kolei obie te cechy, rywalizację oraz niewytłumaczalny (w płaszczyźnie wartości praktycznych) imperatyw, powiąże się ze wspinaniem, to z równą łatwością obie można, w pierwszym odruchu, przypisać naturze męskiej - wszakże kobiety zazwyczaj nie poświęcają swojego życia dla abstrakcji, a jeśli ulegają rywalizacji (choćby w sporcie), to zwykliśmy myśleć, że jest to psychologiczne zapożyczenie od „płci brzydkiej”8.

Wanda Rutkiewicz od początku traktowała góry jako obszar rywalizacji. W filmie Ślady na śniegu w reżyserii Waldemara Helflicha mówi: „Byłam jak zdobywca. Stosunek do gór był taki jak do sportu, chodziło o to, żeby zrobić wynik i zwyciężyć z górą"9 . Jak się później okazało, chodziło nie tylko o zwyciężenie z górą, ale także o to, by być najlepszą w ogóle. Również od mężczyzn lub, inaczej, bez mężczyzn. Nie chciała być postrzegana jedynie przez swoją cielesność (choć niewątpliwie bardzo o nią dbała i byłą świadoma swych atutów, co zresztą, jak można przeczytać w licznych wspomnieniach, chętnie wykorzystywała). Przede wszystkim chciała być postrzegana jako alpinistka, zdolna alpinistka. Wyjście poza utarte schematy nie było

${ }^{6}$ Ibidem.

7 B. Rusowicz, Wszystko o Wandzie Rutkiewicz. Wywiad rzeka Barbary Rusowicz, Toruń-Piła 1992, s. 44.

${ }^{8}$ K. Zanussi, Wstęp, [w:] B. Rusowicz, op. cit., s. 6.

9 Ślady na śniegu, reż. W. Helflich, 1990. 
jednak łatwe. Wchodząc w świat wspinania, mimo faktu, że było w owym czasie relatywnie dużo (chociażby w porównaniu $\mathrm{z}$ dzisiejszymi czasami) naprawdę dobrze wspinających się kobiet, wkraczała w świat męski. Gdy nabrała w górach pewności siebie, chciała dyktować warunki, co w środowisku nie zawsze spotykało się $\mathrm{z}$ aprobatą. Mężczyźni z reguły wolą (jak wspominał w wywiadzie jeden z pierwszych partnerów wspinaczkowych Wandy), żeby kobiety podziwiały ich wspinanie, a nie rządziły. Wanda zaś chciała dominować zarówno w zespołach mieszanych, jak i czysto kobiecych, bo z czasem bliższe stało jej się wspinanie się z kobietami.

Rutkiewicz miała wiele do uwodnienia w męskim świecie gór. Wyprawę w Alpy w 1966 roku, podczas której wraz z Elżbietą Piekarczyk zdobyła Mont Blanc, organizowała za własne pieniądze, gdyż kobiety nie były zwyczajowo zapraszane na takie wyprawy. Andrzej Zawada, himalaista i lider wielu późniejszych narodowych wypraw, który był w Chamonix, gdy Rutkiewicz z Piekarczyk weszły na Mont Blanc, wiele lat później napisał o spotkaniu z Wandą:

Młoda, piękna dziewczyna o czarującym uśmiechu i długich zgrabnych nogach wzbudzała ogólne zainteresowanie. Miała ujmujący sposób bycia. Jakąś wyjątkową łagodność w sposobie poruszania się i mówienia. Mogła być wzorem wytwornej panienki ze szlacheckiego dworu, delikatnej i romantycznej. Zupełnie odbiegała od swoich francuskich rówieśniczek, młodzieżowych feministek o hippisowskim, hałaśliwym sposobie bycia. Początkowo nikt z nas nie zdawał sobie sprawy, że ta spokojna, trochę jakby z innej epoki dziewczyna ma żelazny charakter, ogromną siłę woli i potrafi być niezmiernie zdyscyplinowana w działaniu. Kolejnym zaskoczeniem były jej sprawność fizyczna i siła. Pamiętam, jak któregoś dnia nasi francuscy gospodarze, na swoje nieszczęście, namówili Wandę, by spróbowała się z nimi w zawodach siłowych na rękę. Pokonała wszystkich, choć prosiliśmy ją, żeby ze względów taktycznych poddała się chociaż jednemu, bo przestaną nas zapraszać na wino ${ }^{10}$.

Wanda Rutkiewicz nie wpisywała się w stereotyp słabej, „zależnej kobietki” — mimo iż jej kobiecość nigdy nie była kwestionowana - co niewątpliwie musiało budzić konfuzję wśród męskich członków wypraw. Połączenie jej bardzo kobiecego wyglądu z „okropnym”, jak można przeczytać w niektórych relacjach, charakterem, musiało intrygować.

W 1968 roku Wanda wspólnie z Haliną Krueger-Syrokomską przeszły, jako pierwsze kobiety, jedną z najtrudniejszych tras wielkościanowych na świecie, wschodni filar Trollryggenu. Pierwsze kobiece przejście odnotowały najważniejsze tytuły prasowe w Norwegii, jednak najwięcej miejsca poświęcono im w norweskim odpowiedniku „Playboya” - „Alle Mennen”. „Dwie kobiety w alpinistycznym ubraniu na skale obok gołych dziewcząt na wewnętrznych stronach pisma działały jak prowokacja" - pisze we wspomnieniach Reinhold Messner ${ }^{11}$. Przejście tej drogi sprawiło, że Rutkiewicz została bardziej doceniona w środowisku polskich wspinaczy, co nie zmienia faktu, że nadal nie czuła się najlepiej w męskich zespołach. Mimo że nikt nie mówił

10 A. Zawada, Tylko góry, pięć lat temu zaginęła Wanda Rutkiewicz, „Rzeczpospolita” 13 maja 1997, s. 8 .

11 R. Messner, Na szczycie. Kobiety na górze, Katowice 2012, s. 82. 
tego przy niej otwarcie, uważano, że obecność kobiety w zespole obniża sportową rangę wejścia i Wanda to wyczuwała. Zapewne z tych też względów Wanda, jako pierwsza wśród alpinistek w Polsce, wpadła na pomysł kobiecych wypraw w góry wysokie. Rezultatem tego konceptu była zorganizowana na początku lat 80. kobieca ekspedycja na K2 czy wcześniejsza na Gaszerbrumy. Inspiracją były m.in. międzynarodowe spotkania alpinistek za Zachodzie, tak zwane rendez-vous, w których Rutkiewicz brała udział. Spotkania te organizowała Austriaczka Felicitas von Reznicek, jedna $\mathrm{z}$ pierwszych wspinających się kobiet. W czasie tych spotkań dyskutowano na temat idei wypraw kobiecych, planowanych międzynarodowych ekspedycji w zespołach kobiecych i sytuacji kobiet w górach. W Polsce idea rodziła się w bólach, mężczyźni od początku z niej drwili. Z ust czołowych polskich himalaistów padały żarty typu: „Ciekawe, kto wam będzie plecaki nosił”, z kolei Leszek Cichy (zdobywca zimowego Everestu) przyznał: „traktowaliśmy to jak zawłaszczenie przestrzeni. Być może byliśmy zbyt egoistyczni?"12.

Mimo oporu środowiska, głównie mężczyzn, w 1975 roku Rutkiewicz organizuje swoją pierwszą wyprawę w Himalaje. Poprzeczka zostaje ustawiona bardzo wysoko, gdyż celem kobiet miał być przez nikogo niezdobyty Gaszerbrum III. Na wyprawę tę, oficjalnie by wspierać Polki w kraju muzułmańskim, jadą także mężczyźni, którzy nie dostali pozwolenia na wejście na inny szczyt. To jednak Wanda zostaje kierownikiem wyprawy i to ona wybiera skład. O wyprawie tej mówiła w jednej z książek: „Żeby stworzyć zaufanie i wiarę w samodzielne działanie kobiet w górach, należało przeprowadzić udaną wyprawę. Potrzebny był sukces"13. I ona wzięła na siebie tę odpowiedzialność.

To, co działo się na tej wyprawie w 1975 roku w Karakorum, próbował oddać w filmie Temperatura wrzenia Andrzej Zajączkowski, który towarzyszył z kamerą ekipie w bazie w górach. O ekspedycji rozpisywała się też prasa. „Biorąc pod uwagę sumę wyników, wyprawę można uznać za najowocniejszą w historii polskiego alpinizmu, a jeśli chodzi o alpinizm kobiecy - za najdonioślejszą w ogóle” 14 pisano w „Sportowcu". Nie obyło się jednak bez kontrowersji, gdyż Wanda weszła na Gaszerbrum III w zespole mieszanym, a nie, jak planowano, czysto kobiecym. I choć miało miejsce podczas tej wyprawy czysto kobiece wejście na ośmiotysięczny szczyt, uwaga skupiła się na Wandzie. W środowisku rozgorzał konflikt, Wanda zaś wyjaśniała na łamach prasy: „Pragnęłam tego sukcesu tylko dla kobiet, ustąpiłam w chwili, kiedy trwanie przy tym pragnieniu mogło przekreślić szanse zdobycia szczytu w ogóle"15. Pozostałe uczestniczki miały jednak żal, że Wanda przedłożyła swój własny sukces nad sukces całego zespołu kobiecego. Co więcej, w Temperaturze wrzenia naświetlony

\footnotetext{
12 Himalaiści. Karawana marzeń - Wanda Rutkiewicz, reż. M. Kłosowicz, 2007.

13 W. Rutkiewicz, E. Matuszewska, Na jednej linie, Warszawa 1986, s. 109.

14 K. Blauth, Świetlista ściana Gasherbrum, „Sportowiec” 14 października 1975, s. 3.

15 W. Rutkiewicz, Gasherbrum III zdobyty, „Taternik” 1976, nr 2, s. 63.
} 
został konflikt, do jakiego doszło między kierowniczką wyprawy a zespołem właśnie, co tłumaczyła: „Zespół nie czuł się przeze mnie szanowany, był dotknięty, że nie liczę się z jego zdaniem. A przecież liczyć się ze zdaniem 20 osób jest niezwykle trudno. Demokracja nie jest najlepszą metodą prowadzenia dużych wypraw himalajskich" ${ }^{16}$. Uczestnicy wyprawy podkreślali, że w jej trakcie Rutkiewicz dystansowała się od wszystkich, traktując ludzi instrumentalnie. Zawsze chciała być najlepsza i nie potrafiła przyznać się do błędu ${ }^{17}$. Szczególnie rozczarowane były pozostałe kobiety, które liczyły na czysto kobiece wejście. Tym bardziej że Wanda zawsze powtarzała, że kobiety są spychane na margines przez społeczeństwo. Atmosfera, która panowała na tej wyprawie, do razu stała się pretekstem do powielania kolejnego stereotypu, że kobiety w grupie nie żyją zgodnie, o czym mówiła w jednym z wywiadów:

Przeciętna kobieta nie umie współdziałać z innymi kobietami, ponieważ nie robi tego na co dzień. Wynika to z określonych, tradycyjnych struktur, gdzie jest ona w gospodarstwie domowym panią i władczynią i nie musi współdziałać z drugą kobietą, aby to gospodarstwo funkcjonowało. Natomiast w góry nie jadą przypadkowe kobiety. Jeżdżą alpinistki, które znają swój fach i przyzwyczajone są do działania w grupie. Różnice między kobietami i mężczyznami polegają na tym, że kobiety mniej umiejętnie działają w zespole. Mężczyźni bardzo często przebywają w grupie, więc tworzą ją wręcz instynktownie i nierzadko są od niej uzależnieni. [...] Kobieta działa w domu i ma mniejszą potrzebę tworzenia grupy, bo jej grupa to mąż i dzieci plus sąsiadki ${ }^{18}$.

Jak sama powiedziała w jednym z wywiadów - do czasu tej wyprawy kobiety jeździły w góry głównie jako „ozdobne broszki” ${ }^{19}$. Niewątpliwy sukces z Gaszerbrumów zmienił ten wizerunek.

Rutkiewicz była z czasem coraz bardziej ceniona na Zachodzie, dlatego nie dziwi fakt, że to stamtąd przyszła propozycja wzięcia udziału w niemieckiej ekspedycji na Everest, która odbyła się w 1978 roku. Rozpoczęła się era Wandy Rutkiewicz. Himalaistka spotkała się w trakcie tej wyprawy z niechęcią części niemieckiego zespołu, który nie był w stanie pogodzić się z faktem, iż kierownik wyprawy uczynił ją — kobietę - swoim zastępcą. Zasady dla kobiet (oprócz niej jest jeszcze jedna Niemka, głównie jednak towarzyszy ona swojemu mężowi) są takie same jak dla mężczyzn. Z bazy do góry trzeba wnieść 75 kilogramów i jest to warunkiem podejścia na szczyt. Niemka część swojego bagażu oddaje mężowi, Wanda swój wnosi sama ${ }^{20}$. Mimo niezbyt dobrej kondycji i podupadającego zdrowia, dzięki nieprawdopodobnemu uporowi 16 października 1978 r. wchodzi na najwyższy szczyt świata i zapisuje się w historii. Uczyniła to jako pierwsza spośród polskich wspinaczy, pierwsza Europejka, a trzecia kobieta na świecie. Informacje do Polski trafiają z opóźnieniem, gdyż tego samego dnia Karol Wojtyła zostaje wybrany na papieża i to ta informacja zdomino-

\footnotetext{
16 W. Rutkiewicz, E. Matuszewska, op. cit., s. 128.

17 Zob. szerzej: A. Kamińska, op. cit., s. 237.

18 B. Rusowicz, op. cit., s. 105.

19 Ibidem.

20 Zob. szerzej: A. Kamińska, op. cit., s. 259.
} 
wała polskie media i polską opinię publiczną. Gdy z kilkudniową zwłoką gazety zaczynają rozpisywać się o sukcesie Rutkiewicz, nagłówki krzyczą o „pięknym sukcesie polskiego alpinizmu"21, niewątpliwie w ten sposób nawiązując także do jej urody. Z całego świata płyną gratulacje. W oficjalnej wersji Polski Związek Alpinizmu dołącza do tychże, nieoficjalnie, w kuluarach zaś Andrzej Zawada, który planował już wówczas zimowy, męski wyjazd na Everest, miał powiedzieć: „Mówiłem, żeby nie wysyłać baby na Everest"22. Anegdotę tę, jak można przeczytać u Anny Kamińskiej, potwierdził Andrzej Paczkowski (ówczesny prezes Polskiego Związku Alpinizmu), dodając, że nie tylko Andrzeja Zawadę, lecz także wielu innych polskich himalaistów „szlag trafił”. Pytana w czasie jednej z licznych konferencji prasowych o mężczyzn, uczestników wyprawy powiedziała, nie przebierając w słowach: „nie mogłam liczyć z tego powodu na żadne ulgi. Przeciwnie - mężczyźni baczyli, by ich jedynaczka miała nie mniejsze obowiązki. Drażnił ich chyba nieco fakt, że kobieta jest w stanie znieść to, co z trudem znosili silni i młodzi mężczyźni”"23. Wśród wielu pytań, które padają wtedy z ust dziennikarzy, wiele dotyczy płci: Czy zdarzyło się Pani, wchodząc na Everest, po kobiecemu popłakać? (Nie, nie zdarzyło się). Czy mężczyźni starali się Pani pomagać? (Traktowali mnie po partnersku). Natomiast na pytanie, czy posiadanie dzieci by ją odmieniło (tzn. czy nie ryzykowałaby tak dużo), odpowiedziała „Możliwe, bo jestem mimo wszystko osobą dosyć odpowiedzialną. Wtedy może poczucie obowiązku i odpowiedzialności przeważyłoby, ale nie wiem, czy to mnie by uszczęśliwiło. Wydaje mi się, że nie. Nie czuję potrzeby potwierdzania sensu mojego istnienia przez macierzyństwo" 24 . Było to odważne wyznanie, gdyż mało która z ról społecznych związana jest z taką liczbę mitów, stereotypów, oczekiwań i ocen jak „matka” i rola, jaką jest macierzyństwo. Kobieta bez dziecka nie jest w pełni kobietą, a kobieta z dzieckiem jest już wyłącznie matką. Wedle nurtu tradycyjnie zakorzenionego w społeczeństwie rodzicielstwo uważane jest za obowiązek normalnej kobiety. Kobiety pragnące uchodzić za normalne podlegają obowiązkowi bycia matką, czyli są adresatem nakazu macierzyństwa ${ }^{25}$. Wizerunek Matki Polki jest nierozerwalnie związany z tożsamością większości Polek aż do dziś. Wanda wychodziła także poza ten schemat.

21 Wanda Rutkiewicz wśród zdobywców najwyższego szczytu świata. Piękny sukces polskiego alpini$z m u$, „Trybuna Ludu” 18 października 1978, s. 1.

22 Cyt. za: A. Kamińska, op. cit., s. 267.

23 Zdobywczyni Mount Everestu Wanda Rutkiewicz wróciła do kraju, „Życie Warszawy” 14 listopada 1978, s. 1 .

24 B. Rusowicz, op. cit., s. 42.

25 Por. m.in.: I. Przybył, Konstruowanie tożsamości „potencjalnej” przez niepłodne kobiety, [w:] Kłopoty z tożsamością, „Człowiek i Społeczeństwo” 2006, nr 26, red. M. Golka, s. 284-285; Ł. Wawrowski, Partycypacja kobiet $w$ życiu politycznym w opinii społeczeństwa polskiego, „Wrocławskie Studia Politologiczne" 2004, nr 4, s. 72-73. 
Przy okazji zdobycia Everestu padł absolutny rekord Polski, który mężczyźni mogli już tylko wyrównać. To było osiągnięcie, które w tym momencie zaspakajało jej ambicje. Bowiem Wanda niemal od początku przenosiła sportową rywalizację na płaszczyznę kobieta - mężczyzna. Już od dawna nie satysfakcjonowała jej pierwsza pozycja wśród kobiet. Rutkiewicz odniosła się w jednym z wywiadów do rzekomej rywalizacji. Gdy padło pytanie: „Czy ma dla Pani znaczenie, że wygrywa Pani z mężczyznami, że jest lepsza niż mężczyźni?”, odpowiedziała: „Nie, bo ja nie jestem lepsza niż mężczyźni. Od Jurka Kukuczki jestem gorsza. Najlepsza alpinistka będzie zawsze gorsza niż najlepszy alpinista" ${ }^{26}$. Sam Jerzy Kukuczka skomentował po latach podejście Rutkiewicz do wspinania czysto kobiecego następująco: „Wanda była prekursorką czysto kobiecej działalności w górach. Uważała, że wspinaczka w zespołach mieszanych uwłacza kobiecie, odbiera jej szanse wykazania, że jest zdolna do tego samego co mężczyzna. Dlatego przypuszczam, że dążyła do podzielenia alpinizmu na konkurencję kobiecą i męską"27.

Za sprawą Everestu Wanda zyskała jednak ogromną popularność i jednocześnie ociepliła częściowo wizerunek himalaistów w Polsce, którzy traktowani byli przez społeczeństwo dość niepoważnie. To po Evereście zaczęła się nią interesować polska prasa, w której do tej pory opisywano prawie wyłącznie osiągnięcia mężczyzn, w szczególności rywalizację Jerzego Kukuczki z Reinholdem Messnerem ${ }^{28}$. Zainteresowanie mediów pociągnęło za sobą także wyjątkowe korzyści: reklamę i popularność, które doprowadziły do większego uznania, ale także wsparcia finansowego od firm sponsorskich, z czego Wanda potrafiła umiejętnie korzystać. Wraz z Janem Pawłem II stali się natychmiast żywymi symbolami dla borykającego się z wieloma problemami kraju. Zdobycie Everestu ugruntowało jej pozycję jako himalaistki i polskiej bohaterki. Media ją pokochały, zaś ona potrafiła $\mathrm{z}$ tego zainteresowania umiejętnie korzystać. Wspinająca się na najwyższe góry świata kobieta, ładna kobieta, musiała przykuwać uwagę. Podobnie jak jej poglądy i stosunek do mężczyzn.

W roku 1982 Rutkiewicz organizuje kobiecą wyprawę na K2. Zostaje jej liderem, choć wiadomo, że sama nie będzie zdobywała szczytu ze względu na złamanie nogi. Kobiety, które zostały zaproszone na wyprawę, najlepsze polskie alpinistki, pojechały na K2 ubrane od stóp do głów, wyposażone w zachodni sprzęt i z zapewnioną kuchnią francuską, które Wanda zorganizowała u zachodnich sponsorów, choć w Polsce panował wtedy stan wojenny. Mimo mnożących się przeszkód, wyprawa wyruszyła tylko z niewielkim opóźnieniem. Wanda o kulach przeszła cały lodowiec Baltoro (ponad $120 \mathrm{~km}$ ), a jej zdjęcia obiegły prasę światową. Wyprawa ta nie zakończyła

26 W. Rutkiewicz, 100 pytań do..., rozmowę przeprowadziła A. Grzeszczuk-Gałązka, 1989, cyt. za: A. Kamińska, op. cit., s. 297.

27 J. Kukuczka, Mój pionowy świat, Katowice 2014, s. 62.

28 Świat mediów śledził z zapartym tchem rywalizację Kukuczki z Messnerem o to, który z nich jako pierwszy człowiek na Ziemi zdobędzie koronę Himalajów i Karakorum, czyli wszystkie 14 ośmiotysięcznych szczytów. 
się jednak powodzeniem. Rutkiewicz zdobywa K2, jako pierwsza kobieta na świecie i pierwsza Polka, równocześnie pierwszy polski himalaista, dopiero w 1986 roku i jest to jej największe osiągnięcie w górach wysokich. Mimo coraz słabszej kondycji i podupadającego zdrowia nie potrafiła jednak zrezygnować $\mathrm{z}$ dalszego kompletowania ośmiotysięcznych szczytów.

W 1989 roku, w wieku 46 lat, Rutkiewicz postanawia zdobyć wszystkie ośmiotysięczniki plan swój nazywając „Karawaną do marzeń”, bo jak tłumaczyła „próbuję przeforsować coś, co zdaje się do zrealizowania tylko w marzeniach" ${ }^{29}$. Środowisko patrzyło na to wszystko z niedowierzaniem, choć publicznie oszczędnie wypowiadano się na ten temat. W tamtym czasie Wanda była już postrzegana jako osoba, która zmierza ku zatraceniu, nie ma żadnych zahamowań, a co więcej nie jest w stanie sprostać fizycznie takiemu przedsięwzięciu, choć nie mówiono o tym otwarcie. Wanda była coraz bardziej samotna i wyobcowana. Prawie nikt nie chciał się z nią wspinać. W wywiadzie rzece powiedziała Ewie Matuszewskiej, że nigdy nie spotkała mężczyzny, który wspierałby jakiekolwiek z jej osiągnięć. „Dla każdego z partnerów moje pasje były zagrożeniem, każdy z nich był zazdrosny o czas, który poświęcam innym sprawom. Toteż nie chcąc rezygnować z gór, wybrałam samotność" ${ }^{30}$. Życie Wandy poza przebywaniem $w$ górach sprowadzało się jedynie do tego, by jak najszybciej w nie wrócić. Kolejne szczyty usiłowała zdobyć w pojedynkę. Tak też było w przypadku Kanczendzongi, na której zaginęła w 1992 r.

W czasie trzydziestoletniej kariery wspinaczkowej Rutkiewicz nieraz ocierała się o śmierć. W górach, jak sama wyliczała, straciła ponad trzydzieści bliskich jej osób. W końcu szczęście musiało ją opuścić. Wspinała się coraz wolniej, z coraz większym wysiłkiem, więc zdarzały się jej niebezpieczne sytuacje i nieplanowane postoje. Była jednak zbyt dużą indywidualnością, nie dawała sobie wytłumaczyć, że czas na odpoczynek. W swojej kolekcji miała wiele medali i odznaczeń. Medal Za Wybitne Osiągnięcia Sportowe dostała siedmiokrotnie, w tym trzy razy złoty. Otrzymała również Krzyż Kawalerski Orderu Odrodzenia Polski, Puchar Ministra Spraw Zagranicznych oraz nagrody i odznaczenia zagraniczne: Rolex Award Enterprise, Raichle Abenteurerpreis, francuski Victor of Adventure, włoską Premio Minerva, pakistański order Sitara-e Imtiaz i belgijski Medal Zasługi Króla Alberta I. Należała do tych nielicznych Polek, których nazwiska pojawiały się na czołówkach światowych gazet, a jej głos był słyszalny nie tylko w sprawach alpinizmu, ale także ochrony środowiska, emancypacji kobiet w Azji czy pokoju w Afganistanie ${ }^{31}$. Żadnej z kobiet nie udało się uczynić tak wiele dla przełamania monopolu mężczyzn we wspinaniu się na najwyższe szczyty.

${ }^{29}$ G. Reinisch, Karawane der Traeume, München 1998, s. 156-158.

30 W. Rutkiewicz, E. Matuszewska, op. cit., s. 185.

31 Zob. szerzej: J. Kurczab, Minęło 20 lat od zaginięcia Wandy Rutkiewicz, http://www.wspinanie.pl (dostęp: 10.10.2018). 
Jaki był i jest wizerunek medialny Wandy Rutkiewicz? Nie sposób nie odnieść wrażenia, że był on w dużej mierze wyreżyserowany przez nią samą. Przed autoryzacją dokładnie czytała każdy wywiad, potrafiła zwlekać z publikacją poszczególnych wypowiedzi, o czym można przeczytać w tekście Krzysztofa Mroziewicza Wyżej tylko niebo ${ }^{32}$. W jednym $\mathrm{z}$ wywiadów radiowych (była bardzo częstym gościem Polskiego Radia) słychać jak kokietuje publiczność oraz prowadzącego Jana Tyszkiewicza, mówiąc, że jeśli kiedykolwiek porzuci góry, zostanie redaktorką radiową ${ }^{33}$. Media lubią ludzi sukcesu, a jako taka z pewnością mogła być postrzegana Wanda Rutkiewicz. Zawsze uśmiechnięta, zawsze elegancka i zadbana. To też znamienne, że na większości zdjęć, oczywiście oprócz zdjęć z Everestu czy zdjęcia o kulach w drodze do bazy pod K2, które media pokochały, większość fotografii przedstawia właśnie elegancką, zadbaną kobietę, w nienagannej pozie z promiennym uśmiechem na twarzy. Wanda lubiła dobre ubrania, perfumy ${ }^{34}$ - podobno potrafiła wydać na nie ostatnie pieniądze, tak bardzo liczył się dla niej jej wizerunek i co inni o niej pomyślą. Potrafiła je zabrać ze sobą w góry. Chcąc żyć z profesjonalnej wspinaczki - jej wzorem w tej materii był Reinhold Messner, uczyła się, jak umiejętnie, także wykorzystując media, budować swój wizerunek.

Wanda Rutkiewicz była postacią, która budziła wiele emocji. Jej odbrązawianie nastąpiło w gruncie rzeczy wiele lat po jej śmierci. W czasach PRL-u, gdy nie mówiło się zbyt dużo o tradycyjnej roli kobiety w rodzinie, Rutkiewicz była kolorowym ptakiem, który budził zarówno zachwyt, jak i niepokój. Socjalizm nie był rajem dla kobiet (zresztą dla nikogo nie był), ale paradoksalnie wizerunek wspinającej się kobiety (parafrazując słowa Magdaleny Środy o kobietach na traktorach ${ }^{35}$ ), był w pewnym sensie symbolem rzeczywistej emancypacji. Wyjście kobiety ze strefy prywatnej do publicznej - a Wanda znakomicie odnajdywała się w jej realiach — dokonało się szybciej niż zmiana stereotypów dotyczących słabszej płci. Zresztą to w tamtych czasach w górach wysokich wspinało się (i to na naprawdę wysokim poziomie) zdecydowanie więcej kobiet niż ma to miejsce obecnie. Pamięć o Wandzie Rutkiewicz została ukształtowana dopiero w przeciągu ostatnich kilku lat. Po jej tragicznym zaginięciu na Kanczendzondze w 1992 roku, kiedy to media rozpisywały się na jej temat, nastała cisza. Nie było nikogo (wynikało to zapewne z jej skomplikowanych relacji z otoczeniem) kto zadbałby o tę pamięć i sprawił, że funkcjonowałaby ona szerzej w sferze publicznej. To na przestrzeni ostatnich kilku lat, i to za sprawą innych kobiet $^{36}$, pamięć o Wandzie została częściowo przywrócona. Jednak oprócz zrozumiałego zainteresowania jej osiągnięciami sportowymi, o wiele więcej miejsca poświęca

32 K. Mroziewicz, Wyżej tylko niebo, „Polityka” 12 lipca 1992, s. 1, 12.

33 https://www.polskieradio.pl/68/787/Tag/17594 (dostęp: 10.10.2018).

34 P. Nowicki, Świat u stóp Wandy, „Wprost” 3 czerwca 2018.

35 Zob. szerzej: M. Środa, Kobiety i władza, Warszawa 2009.

${ }^{36}$ W ostatnim czasie powstały m.in. biografie pióra Anny Kamińskiej, Elżbiety Sieradzińskiej, dwa monodramy, trwają także prace nad filmem fabularnym w reżyserii Elizy Kubarskiej. 
się tragizmowi jej postaci. Pamięć o Wandzie Rutkiewicz to bowiem nie tylko pamięć o jej alpinistycznych sukcesach, to także wspomnienia o niej samej. Jej bezkompromisowość (zarówno w stosunku do siebie, jak i do świata), a także wyjście poza utarte schematy ówczesnych realiów kulturowych, czynią z niej bohaterkę w gruncie rzeczy dramatyczną. Taki obraz Wandy wyłania się zarówno z biografii jej poświęconych, jak i monodramów, które powstały w ostatnich latach. Co ważne, także w wymiarze lokalnym coraz więcej miejsca poświęca się pamięci o najsłynniejszej polskiej himalaistce. Z okazji stulecia polskiej niepodległości i przyznania kobietom praw wyborczych we Wrocławiu powstaje mural, który ma upamiętnić Wandę Rutkiewicz.

\section{Bibliografia}

Blauth K., Świetlista ściana Gasherbrum, „Sportowiec” 14 października 1975.

Hansen P.H., The Summits of Modern Man: Mountaineering after the Enlightenment, Cambridge-Massachusetts-London 2013.

Himalaiści. Karawana marzeń - Wanda Rutkiewicz, reż. M. Kłosowicz, 2007.

https://www.polskieradio.pl/68/787/Tag/17594 (dostęp: 10.10.2018).

Jordan J., Okrutny szczyt, Wrocław 2007.

Kamińska A., Wanda. Opowieść o sile życia i śmierci. Historia Wandy Rutkiewicz, Kraków 2017.

Kukuczka J., Mój pionowy świat, Katowice 2014.

Kurczab J., Minęło 20 lat od zaginięcia Wandy Rutkiewicz, www.wspinanie.pl (dostęp: 10.10.2018).

Messner R., Na szczycie. Kobiety na górze, Katowice 2012.

Mroziewicz K., Wyżej tylko niebo, „Polityka” 12 lipca 1992.

Nowicki P., Świat u stóp Wandy, „Wprost” 3 czerwca 2018.

Przybył I., Konstruowanie tożsamości „potencjalnej” przez niepłodne kobiety, [w:] Kłopotyz tożsamościa, „Człowiek i Społeczeństwo” 2006, nr 26, red. M. Golka.

Reinisch G., Karawane der Traeume, München 1998.

Rusowicz B., Wszystko o Wandzie Rutkiewicz. Wywiad Rzeka Barbary Rusowicz, Toruń-Piła 1992.

Rutkiewicz W., Gasherbrum III zdobyty, „Taternik” 1976, nr 2.

Rutkiewicz W., Matuszewska E., Na jednej linie, Warszawa 1986.

Ślady na śniegu, reż. W. Helflich, archiwum TVP, 1990.

Środa M., Kobiety i władza, Warszawa 2009.

Wanda Rutkiewicz wśród zdobywców najwyższego szczytu świata. Piękny sukces polskiego alpinizmu, „Trybuna Ludu” 18 października 1978.

Wawrowski Ł., Partycypacja kobiet $w$ życiu politycznym $w$ opinii społeczeństwa polskiego, „Wrocławskie Studia Politologiczne" 2004, nr 4.

Zanussi K., Wstęp, [w:] Wszystko o Wandzie Rutkiewicz. Wywiad Rzeka Barbary Rusowicz, Toruń-Piła 1992.

Zawada A., Tylko góry, pięć lat temu zaginęła Wanda Rutkiewicz, „Rzeczpospolita” 13 maja 1997.

Zdobywczyni Mount Everestu Wanda Rutkiewicz wróciła do kraju, „Życie Warszawy” 14 listopada 1978. 


\section{A woman on the roof of the world or on Wanda Rutkiewicz's story and media image}

\section{Summary}

The story of Wanda Rutkiewicz is extraordinary for several reasons. It is a story of a woman for whom her passion was the most important thing in life. She subordinated all her life to this passion - the mountains. In order to reach the summits she desired, she had to battle not only her own weaknesses, fear or power of nature, but also common beliefs which stereotypically defined the role of women in society. Women who, through climbing, "ventured" into the territories usually occupied by men often provoked feelings of misunderstanding, reluctance, irritation and even opposition among the public at large, especially men. However, Rutkiewicz went beyond many widely-held beliefs. Her independence, skills and conscious creation of her own image (also thanks to her skilful use of the media's interest) were admirable. Although her journey ended tragically, through her activities in the high mountains she made history of not just Polish mountaineering but also women's mountaineering.

Keywords: woman, Himalayan mountaineering, stereotype, media, image 